\title{
YOUTH PURPOSEFULNESS FACILITATING SUBJECTIVE AND OBJECTIVE FACTORS IN LIFE ACTIVITIES AT SCHOOL
}

\begin{abstract}
The present article reviews life activities as a form of existence, manifesting itself in real actions in various aspects of one's life within its interaction with the external environment. The Aim of the Study was brought forth - to analyse the results of empirical research on youth purposefulness facilitating factors in life activities at school and compare the differences of the factors on groups of youth from the $9^{\text {th }}$ and $12^{\text {th }}$ grade.

The present article reviewed the self-assessment results of youth purposefulness facilitating subjective and objective factors' in two attempts - in $9^{\text {th }}$ grade (2008) and in 12 th grade (2011), as well as the dynamics of such factors. The results revealed a positive youth purposefulness formation dynamics over time as well as the results uncovered profound differences within the objective factors associates with the role of school in the facilitation of purposefulness and selfassessment.

The article summarises the major conclusions, which indicate that the subjective and objective pedagogical realities are linked in terms of youth purposefulness facilitation which manifests itself as a relation between the subjective and objective factors. Such subjective and objective factors differ depending on the young person's age which in turn is indicated by the substantial shift of self-assessment results concerning the evaluation of purposefulness facilitating subjective and objective factors. The findings indicate towards very urgent matters that must be addressed in the course of the pedagogical process by planning and managing the development of youth purposefulness.
\end{abstract}

Keywords: purposefulness, youth, purposefulness facilitating subjective and objective factors

\section{INTRODUCTION}

The justification of the study on youth purposefulness facilitating subjective and objective is supported by the conclusions of the study that the part of the youth who forecasted a positive outcome of its goals in $2 / 3$ of the cases associated one's positive outcome with internal positions, but external conditions were indicated by less than $5 \%$. A part of youth, who forecasted negative outcomes, less than $50 \%$ of the said part deemed internal conditions as essential and more than $40 \%$ of them emphasized the importance of the external factors (Phinney, Baumann \& Blanton, 2001). During the youth age, including adolescence, both professional aspirations and career development goals are being refined and balanced, an actual synchronisation between the said and one's personal qualities takes place including characteristics, interests, goals and conditions one is exposed to in external environment (Hirschi, 2010).

A goal is related to the intention behind action. Intentions acknowledge a certain need - to set an action goal thus turning it into a involved and exciting activity (Леонтьев, 2005; Gudjons, 2007; Maslo, 2003). 
The study illustrates the importance of objective factor interpersonal interaction (i.e. a young person - teacher) in the efficiency of setting and achieving ones goals in relation to the subjective factor - self-regulation, insufficiently development self-regulation skills in terms of setting and achieving ones goals, self-esteem and autonomy (Sanz De Acedo Lizarraga et al., 2006; Kalavana, Maes \& Gucht, 2010). The study discovers the link between the purposefulness and subjective factors of youth personality - self-regulation, emotionality, independence and sociability as well as an insufficiently and realised self-experience (Sanz De Acedo Lizarrage et al., 2006; Špona, Čamane, 2009; Sue Lyn, Martin, Huber Marshall \& Sale, 2000). This constitutes the necessity of the objective factor - to facilitate the development of subjective factors in the course of the educational process.

\section{THE AIM OF THE STUDY}

To analyse the results of empirical research on youth purposefulness facilitating factors in life activities at school and compare the differences of the factors on groups of youth from the $9^{\text {th }}$ and $12^{\text {th }}$ grade.

\section{MATERIALS AND METHODS}

The subjective and objective factors of youth purposefulness were defined based on purposefulness theories (Леонтьев, 2005; Caughlin, 2010); purposefulness research analysis (Yeager \& Bundick, 2009; Vasalampi, Salmela-Aro \& Nurmi, 2010; Schapiro et al., 2009).

A life activity is defined as a dynamic form of being consisting of certain integral types of activity, in which the life activity goal function as a life path project and its implementation is an important aspect of youth purposefulness research (Абульханова-Славянская, 1991). Life activity in particular manifests itself in various walks of life within their interaction with the external environment. The external environment provides both beneficial and least beneficial conditions for one's successful life activity (Братусь, 1988). The author argues that life activity must be analysed in the subject of pedagogy in the context of procedural aspect (Špona, Čehlova, 2004). In this perspective life activity involves both subjective and objective pedagogical realities and an interaction between the two. It enables the definition of the life activity structure at school, which includes:

1. Objective pedagogical reality (teacher personality characteristics, his/her influence dynamics, influence situation, implementation of influence during the interaction of learning process and during extra curriculum activities) and

2. Subjective reality (the field of student motivation (including purposefulness), cognition potential, student's personality characteristics, defining the objective reality influence strength and consequences of, concerning further life activities.

Researcher opinions on youth goal setting skill development stages were taken into account during the definition process of youth purposefulness subjective, the said skills being imperative in formation of one's future plans (Yeager \& Bundick, 2009). Youth self-confidence in the fact that they may achieve their goals are of utmost importance as well as the fact that they know what they require in order to achieve such goals; thoughts on the expected results and keeping in mind one's future plans (Phinney, Bauman \& Blanton, 2001). An uncertainty of one's skills may result in fear of setting specific future plans. Thus the studies show a positive dynamics of goal setting skill development and overall purposefulness in the groups of youth from $6^{\text {th }}$ to $9^{\text {th }}$ to the $12^{\text {th }}$ grade.

Upon analysing self-regulation that is associated with short-term and long-term strain in setting goals, planning activities, activating incentive, psychoanalyst V. Meissner divides between 
three stages of self-regulation: choice of goals, impulse of activity for the achievement of the desired goal, monitoring direction towards the achievement of the goals (Meissner, 2009).

It is concluded that as early as from the age of 14, young persons start to assess their interests and goals; however the sense of self-efficacy is of real importance here (Lent, Taveira, Sheu \& Singley, 2009). Perspectives on self-efficacy influence perspectives on needs, goals which in turn alter one's behaviour. It advertently affects perspectives on self-efficacy, whereas it further defines the achievement progress of one's self-realisation necessities - towards accomplishments or avoidance from failures. Thus the achievement need theory and verities derived from are of real importance in terms of purposefulness research (Elliot, 1997; Elliot \& Church, 1997; Elliot \& Thrash, 2001, as quoted from Barkoukis, Thogersen-Ntoumani, Ntoumanis \& Nikitaras, 2007). This theory illustrates the link between self-regulation and achievement oriented behaviour and an association between the needs of accomplishment and the set achievement goals. There are three distinct goals generated by the youth inclination towards achievement: 1) A goal of mastery or progress towards completing a task; 2) A goal to involve in the completion of the task in order to display one's accomplishment in comparison with others, i.e., achievement motivation; 3) Avoidance from the completion of the goal, to hide one's lack of skill, i.e., avoidance motivation. The goals may serve as a basis for the clarity of youth goal realisation, accuracy and decision making concerning the goals as well as to youth perspective on the matter of how people should be prepared in a modern school.

The link between the subjective and objective factors is supported by the findings of the research - the extent of which youth goal achievement internal conditions such as needs, abilities affection and external, e.g., luck (chance), is of real importance (Phinney, Bauman \& Blanton, 2001). Youth set their goals based on one's intentions and abilities and by adjusting these to the external environment (Vasalampi \& Salmela-Aro-Nurmi, 2010; Hirschi, 2010).

One of the intrinsic factors facilitating youth purposefulness is teacher's activity which influences young person's life activity at school. The first task that shall be undertaken by the teachers is to provide assistance to the student in setting one's life goal as well as assisting the student in realising one's uniqueness and singleness (Gudjons, 2007). Realisation of goals and implementation of, at school may facilitate problem oriented subjects, such subjects involving a development of purposefulness facilitating factors, i.e., the development of critical thought (Amster, 2008), acquisition of authentic experience (Torp \& Sage, 2002), consolidation of collaboration behaviour (Remedios, Clarke \& Hawthorne, 2008).

Upon performing the theory and research analysis on the formation of youth purposefulness, the author concluded that it is possible to distinct between various subjective and objective factors that facilitate youth purposefulness, however, this article analyses the following youth purposefulness facilitating subjective factors: an ability to realise a goal, an ability to set a goal, an ability to select means to achieve a goal; an ability to apply such means in the course of achieving the goal; a need to achieve a goal; future plans; activities concerning the formation of future plans as well as the following youth purposefulness facilitating objective factors concerning life activities at school - school's role in the facilitation of the purposefulness; school's importance in facilitating the ability to set goals; school's role in facilitating the abilities required to achieve the set goals.

The empirical research involves a survey created by the author consisting of statements for the assessment of purposefulness facilitating subjective and objective factors. The sample of the research consisted of 104 students from colleges and secondary schools of Riga; 52 
young persons - students of $9^{\text {th }}$ grade (in the attempt in 2008) and the exact same 52 young persons - students of $12^{\text {th }}$ grade (in the attempt in 2011). The selection was based on the nonprobable selection of "Convenience method". Both frequency divisions and Wilkinson's test was used to the determine the difference between the results obtained from $9^{\text {th }}$ and $12^{\text {th }}$ grade students in the course of research results analysis, but Pearson's Correlation Ratio was used to analyse the interaction between the subjective and objective factors.

\section{RESULTS}

The comparison of youth purposefulness facilitating factors' self-assessment results (see Table 1) - it indicates a positive purposefulness dynamics during over the respective period of time, i.e., that students of $12^{\text {th }}$ grade are more purposeful.

Table 1. Statistically important differences in the purposefulness facilitating subjective factors self-assessment by students of $9^{\text {th }}$ and $12^{\text {th }}$ grades

\begin{tabular}{|c|c|c|c|c|}
\hline Criteria & $\begin{array}{c}\text { Significance }- \text { is or is not } \\
\text { a statistically significant } \\
\text { difference }\end{array}$ & $\begin{array}{l}\text { Average } \\
\text { rank }\left(9^{\text {th }}\right. \\
\text { Grade })\end{array}$ & $\begin{array}{l}\text { Average } \\
\text { rank }\left(12^{\text {th }}\right. \\
\text { Grade })\end{array}$ & $\begin{array}{l}\text { Results } \\
\text { dynamics }\end{array}$ \\
\hline A ability to realise a goal & $.017($ yes $)$ & 13.57 & 12.82 & Negative \\
\hline A ability to set a goal & $\begin{array}{c}.000 \\
(\text { yes }- \text { very significant })\end{array}$ & 11.00 & 11.00 & $\begin{array}{c}\text { No } \\
\text { dynamic }\end{array}$ \\
\hline $\begin{array}{l}\text { An ability to select means for the } \\
\text { achievement of the goal }\end{array}$ & $.002($ yes $)$ & 8.50 & 10.85 & Positive \\
\hline $\begin{array}{l}\text { An ability to use the selected } \\
\text { means for the achievement of } \\
\text { the goal }\end{array}$ & $\begin{array}{c}.000 \\
\text { (yes }- \text { very significant) }\end{array}$ & 11.50 & 12.08 & Positive \\
\hline A need to achieve a goal & .005 (yes) & 19.17 & 15.24 & Negative \\
\hline Future plans & $.418(\mathrm{no})$ & 11.00 & 15.50 & Positive \\
\hline $\begin{array}{l}\text { Activities concerning formation } \\
\text { of future achievements }\end{array}$ & .468 (no) & 18.07 & 17.95 & Negative \\
\hline
\end{tabular}

A higher negative rank average rating may be explained with a comparatively larger number of respondents in the assessment which did not exhibit any changes upon comparison of the both attempts, and the amount of respondents showed higher results in grade $9^{\text {th }}$ than in the $12^{\text {th }}$ grade. The measure of "ability to set a goal" exhibits a statistically significant difference in the results; however, as shown by the statistical estimate trend, it may not be defined as a development dynamic.

Upon performing a detailed analysis on the statistically significant differences in the dynamics of subjective factor assessment, it must be noted that in both attempts (in $9^{\text {th }}$ and $12^{\text {th }}$ grade) there was a limited number of respondents not realising any gals (four in $9^{\text {th }}$ grade and 1 in $12^{\text {th }}$ grade). A positive dynamic is supported by the fact that the statement of "I occasionally realise the goal of my actions" was dominant in $9^{\text {th }}$ grade (50 per cent), while in $12^{\text {th }}$ grade the statement of "I always realise the goal of my actions" was prevailing (57.7 per cent). If 61.5 per cent if the youth in $9^{\text {th }}$ grade deemed that they could set a gal on occasional basis then in $12^{\text {th }}$ grade the same percentage of youth believes that they are always able of setting a goal. A significant indicator in positive dynamics of ability to select means for achievement of the goals 
is that in $9^{\text {th }}$ grade 15.4 per cent of the youth were unable to select efficient means to achieve one's goals; whereas in $12^{\text {th }}$ grade only 3.8 per cent held the latter opinion. Also the youth of $12^{\text {th }}$ grade believe at a more frequent rate that they are able to select efficient means to achieve a goal (50 per cent) - comparing to 25 per cent in $9^{\text {th }}$ grade.

Youth's ability to apply the selected means of the achievement of the goals has also taken a turn for the better with 17.3 per cent in $9^{\text {th }}$ grade believed that they are unable of rational application of the means in order to achieve the goals, however, there are no such respondents in $12^{\text {th }}$ grade. Nevertheless, this criterion is dominated by the statement "I am occasionally able to rationally apply means of the achievement of the goals ( 50 per cent in $9^{\text {th }}$ grade and 55 per cent in $12^{\text {th }}$ grade). Thus in the aspect of action the positive dynamic is not as high as observed for the previous criteria, which were primarily associated with the cognitive aspect.

A very high dynamic may be observed in the assessment concerning the need to achieve a goal: if in $9^{\text {th }}$ grade 32.7 per cent of the youth exhibited a need of a goal, then in $12^{\text {th }}$ grade this percentage reached 75 per cent. Upon analysing youth perspectives on future plans, it may be concluded that a trend not to be concerned with future plans is more characteristic to $9^{\text {th }}$ grade (19.2 per cent), while in $12^{\text {th }}$ grade such view is held only be 7.7 per cent of the youth. If in $9^{\text {th }}$ grade youth is mostly thinking of one's future goals $(67.3$ per cent) and a clear realisation concerning such goals is held only by 9.6 per cent of the youth, then in $12^{\text {th }}$ grade future goals are clearly realised by 38.5 per cent of the youth, this figure only being slightly passed by the view that the person is only thinking of one's future goals (48.1 per cent). However, these differences in results are not of statistical significance.

Youth's take on the fact how they are seeking the direction of their future success activities is an important purposefulness factor -, i.e., a criterion which displays a specific action towards a formation of future success. A positive purposefulness dynamic in $12^{\text {th }}$ grade is supported by the seldom selected statement of intuition and chance (15.4 per cent) and an overall acknowledgement of specific actions - none respondents deemed such action necessary.

A results' dynamic was also observed in the assessment of objective factors upon comparing the results acquired from the attempts in $9^{\text {th }}$ and $9^{\text {th }}$ grade (see Table 2 ).

Table 2. Statistically important differences in the purposefulness facilitating objective factors self-assessment by students of $9^{\text {th }}$ and $12^{\text {th }}$ grades

\begin{tabular}{|l|c|c|c|c|}
\hline \multicolumn{1}{|c|}{ Criteria } & $\begin{array}{c}\text { Significance }- \text { is or } \\
\text { is not a statistically } \\
\text { significant difference }\end{array}$ & $\begin{array}{c}\text { Average } \\
\text { rank }\left(9^{\text {th }}\right. \\
\text { Grade) }\end{array}$ & $\begin{array}{c}\text { Average } \\
\text { rank }\left(12^{\text {th }}\right. \\
\text { Grade) }\end{array}$ & $\begin{array}{c}\text { Results } \\
\text { dynamics }\end{array}$ \\
\hline $\begin{array}{l}\text { School's role in the facilitation } \\
\text { of purposefulness }\end{array}$ & $\begin{array}{c}.001 \\
\text { (yes - very significant) }\end{array}$ & 21.10 & 16.27 & Negative \\
\hline $\begin{array}{l}\text { School's importance in the } \\
\text { facilitation of the ability to set } \\
\text { goals }\end{array}$ & .003 (yes) & 11.00 & 11.61 & Positive \\
\hline $\begin{array}{l}\text { School's role in facilitating the } \\
\text { skills to achieve the set goals }\end{array}$ & .050 (yes) & 13.50 & 11.61 & $\begin{array}{c}\text { No } \\
\text { dynamic }\end{array}$ \\
\hline
\end{tabular}

Comparison of results provided (see Table 2) support the claim that in general, school's role in terms of the purposefulness facilitation is valued higher by the youth of $9^{\text {th }}$ grade; while 
school's importance in facilitating the abilities to set goals is evaluated higher by the youth of $12^{\text {th }}$ grade; finally, no results' dynamic is observed in terms of the factor of "School's role in facilitating the skills to achieve the set goals", difference significant indicator is $p=0.05$ within the borders of significant and non-significant. The acquired results display the following trendthe youth of $12^{\text {th }}$ grade more frequently assessed objective factors in life-activities at school in terms of purposefulness facilitation higher.

Upon analysing correlation results between the purposefulness facilitating subjective and objective factors, it was observed that no statistical significance $(p<0.05)$ between the factors was established in the attempt with the $9^{\text {th }}$ grade. Whereas, in the correlation analysis concerning the $12^{\text {th }}$ grade a statistically significant $(\mathrm{p}<0.05)$ medium interactions were observed between the ability to realise one's goal and school's role concerning the facilitation of skills to achieve the set goals $(\mathrm{r}=.28)$; between the ability to select means to achieve the goals and school's importance in the facilitation of skills to achieve the set goals $(\mathrm{r}=.30)$; between the ability to apply means for the achievement of the goal and school's importance in the facilitation of the ability to achieve the set goals $(\mathrm{r}=.324)$.

\section{CONCLUSIONS}

The subjective and objective realities are linked in terms of youth purposefulness facilitation, which is confirmed by the statistically significant relations among purposefulness facilitating subjective and objective factors. Subjective and objective factors are subject to variation over the various stages of young person's development, which in turn is confirmed by significant self-assessment on youth purposefulness facilitating subjective and objective factors' self-assessment result between the sample of $9^{\text {th }}$ grade and the sample of $12^{\text {th }}$ grade.

The self-assessment results on youth purposefulness facilitating subjective factors demonstrate an overall positive purposefulness assessment dynamic over time, i.e., the youth in $12^{\text {th }}$ grade assess themselves as more purposeful. A trend was also observed that the positive dynamic in the purposefulness factors associated with action was of lesser extent than the dynamic associated with factors of cognitive aspect. Correlation analysis among purposefulness facilitating subjective and objective factors show that in $9^{\text {th }}$ grade this relation is not significant, nevertheless, the results obtained in $12^{\text {th }}$ grade show that the school plays a focal role in the development of youth purposefulness by facilitating youth's ability to realise one's goals, an ability to select means for the achievement of the goal, an ability to apply such means in the course of achievement of the goal. Youth purposefulness facilitating factors in life activity at school improve which in turn hints towards pedagogical management abilities in terms of youth purposefulness development. The obtained results reveal urgent matters that must be addressed in the pedagogical proves by planning and managing the development of youth purposefulness.

\section{REFERENCES}

Amster, B. J. (2008). Problem-based learning in fluency and stuttering. Perspectives on Fluency and Fluency Disorders, 18 (1), 43-47.

Barkoukis, V., Thøgersen-Ntoumani, C., Ntoumanis, N., \& Nikitaras, N. (2007). Achievement goals in physical education: Examining the predictive ability of five different dimensions of motivational climate. European Physical Education Review, 13 (3), 267-286.

Caughlin, J. P. (2010). A multiple goals theory of personal relationships: Conceptual integration and program overview. Journal of Social and Personal Relationships, 27 (6), 824-848. 
Gudjons, H. (2007). Pedagogijas pamatatziņas [Basic ideas of pedagogy]. Rīga: Apgāds Zvaigzne ABC,151.; 224.; 250. lpp. (in Latvian).

Hirschi, A. (2010). Vocational interests and career goals: Development and relations to personality in middle adolescence. Journal of Career Assessment, 18 (3), 223-238.

Kalavana, T. V., Maes, S., \& de Gucht, V. (2010). Interpersonal and self-regulation determinants of healthy and unhealthy eating behavior in adolescents. Journal of Health Psychology, 15 (1), 44-52.

Lent, R. W., Taveira, M. D. C., Sheu, H., \& Singley, D. (2009). Social cognitive predictors of academic adjustment and life satisfaction in Portuguese college students: A longitudinal analysis. Journal of Vocational Behavior, 74 (2), 190-198.

Maslo, E. (2003). Mācīšanās spēju pilnveide [The development of learning skills]. Rīga: RaKa, 40., 54., 91. lpp. (in Latvian).

Meissner, W. W. (October, 2009). Volition and Will in Psychoanalysis. Journal of the American Psychoanalytic Association, 57 (5), 1123-1156.

Phinney, J. S., Baumann, K., \& Blanton, S. (2001). Life goals and attributions for expected outcomes among adolescents from five ethnic groups. Hispanic Journal of Behavioral Sciences, 23 (4), 363-377.

Remedios, L., Clarke, D., \& Hawthorne, L. (2008). Framing collaborative behaviors: Listening and speaking in problem-based learning. The Interdisciplinary Journal of Problem-based Learning, 2, Issue 1.

Sanz De Acedo Lizarraga, M. L., et al. (2006). Goals and personality in adolescents. School Psychology International, 27 (3), 370-381.

Schapiro, M., Schneider, B. H., Shore, M. B., Margison, J. A., \& Udvari, S. J. (2009). Competitive goal orientations, quality, and stability in gifted and other adolescents' friendships: A test of Sullivan's theory about the harm caused by Rivalry. Gifted child quarterly. Sage Journal, 53 (2), 71-88.

Špona, A., Čamane, I. (2009). Audzināšana. Pašaudzināšana [Education, Self-education]. Rīga: RaKa, 260 lpp. (in Latvian)

Špona, A., Čehlova, Z. (2004). Pētniecība pedagogiijā [Research in Pedagogy]. Rīga: RaKa, 204 lpp. (in Latvian).

Sue Lyn, G., Martin, J. E., Huber Marshall, L., \& Sale, R. P. (2000). Promoting self-determination: Using take action to teach goal attainment. Career Development for Exceptional Individuals, 23 (1), 27-38.

Torp, L., \& Sage, S. (2002). From problems possibilities: Problem-based learning for K-16 education ( $2^{\text {nd }}$ ed.) (pp. 15-16). Alexandria, VA: Association of Supervision and Curriculum Development.

Vasalampi, K., Salmela-Aro, K., \& Nurmi, J. E. (2010). Education-related goal appraisals and self-esteem during the transition to secondary education: A longitudinal study. International Journal of Behavioral Development, 34 (6), 481-490.

Yeager, D. S., \& Bundick, M. J. (2009). The role of purposeful work goals in promoting meaning in life and in schoolwork during adolescence. Journal of Adolescent Research, 24 (4), 423-452.

Абульханова-Славская, К. А. (1991). Стратегия жизни [The strategy of life]. Москва: Мысль, 299 с. (in Russian).

Братусь, Б. С. (1988). Аномалии личности [Abnormalities of personality]. Москва: Мысль, 301 с. (in Russian).

Леонтьев, А. Н. (2005). Деятельность. Сознание. Личность [Activity. Consciousness. Personality]. Москва: Смысл, с. 153-154, 205, 346. (in Russian).

Mg. paed., PhD student Māra Bernande

Riga Teacher Training and Educational Management Academy

Address: Bauskas iela 104a, Rīga

Phone: 29193304

E-mail: mara.bernande@gmail.com 